https://doi.org/10.32689/2617-2224-

2021-1(26)-137-146

\title{
Мариенко Людмила Юріївна,
}

аспірант кафедри управління персоналом та економіки прачі ХарРІ НАДУ, заступник начальника управління, начальник відділу обслуговування розпорядників коштів та інших клієнтів Управління Державної казначейської служби України в м. Харкові, 61051, м. Харків, вул. Клочківська, буд. 276-Б кв. 107, тел.: +38 (067) 77747 05, e-mail: marcheluda@ gmail.com, https://orcid.org/0000-00033577-0630

\section{Марченко Людмила Юрьевна,}

аспирант кафедры управления персоналом и экономики труда ХарРИ НАГУ, заместитель начальника управления, начальник отдела обслуживания распорядителей средств и других клиентов Управления Государственной казначейской службы Украины в г. Харькове, 61051, г. Харьков, ул. Клочковская, д. 276-Б кв. 107, тел.: +38 (067) 77747 05, e-mail: marcheluda@gmail. com, https://orcid.org/0000-0003-3577-0630

\section{Marchenko Lyudmila Yuryeona,}

post-graduate student of Personnel Management and Labour Economics Department, KRI NAPA, Deputy Head of Department - Head of the Service Department for Funds Managers and Other Clients, Department of State Treasury Service of Ukraine in Kharkiv City, 61051, Kharkiv, Str. Klochkivska, h. 276-B.f. 107.tel.: +38 (067) 77747 05, e-mail: marcheluda@ gmail.com, https://orcid.org/0000-0003-3577-0630

\section{ОПТИМІЗАЦІЯ РЕСУРСНОГО ЗАБЕЗПЕЧЕННЯ ОРГАНІВ КАЗНАЧЕЙСТВА: АРХЕТИПНИЙ ПІДХІД}

Анотація. Відзначено, що теорія архетипів розроблена Карлом Юнгом в рамках вчення про колективне несвідоме. Зазначено, що в сучасних умовах реформування суспільства, органів державного управління, переходу на новітні інформаційні технології вкрай важливо безперебійне функціонування системи органів Казначейства та управління всіма наявними ресурсами: матеріальними, трудовими, фінансовими тощо. Саме тому проблема належного ресурсного забезпечення в органах Казначейства стоїть надзвичайно го- 
стро. 3 метою ефективного виконання реалізації державної політики у сфері казначейського обслуговування бюджетних коштів органи Казначейства повинні на достатньому рівні забезпечуватися ресурсами. Здійснена оцінка сучасного стану ресурсного забезпечення органів Казначейства в розрізі трьох важливих складових, а саме: придбання предметів, матеріалів, обладнання та інвентарю; оплата послуг (крім комунальних); придбання обладнання і предметів довгострокового користування. Розглянуто проблемні питання щодо матеріально-технічного забезпечення органів Казначейства. Висвітлено коло здобутків в частині покращення матеріально-технічного забезпечення органів Казначейства.

Обгрунтовано засади подальшої оптимізації ресурсного забезпечення органів Казначейства, а саме: надання обгрунтованих пропозицій Міністерству фінансів України щодо затвердження бюджетних призначень для здійснення закупівлі сучасного комп'ютерного обладнання, оргтехніки, програмного забезпечення; здійснення пошуків альтернативних фінансових ресурсів для проведення доопрацювання, модернізації та осучаснення існуючого програмного забезпечення (розробка та затвердження на регіональному рівні програм модернізації матеріального забезпечення органів Казначейства та отримання субвенції з місцевого бюджету до державного бюджету для проведення видатків); створення належних санітарно-побутових умов для ефективного виконання функціональних обов'язків працівників (поступове облаштування робочих місць вентиляторами, системами кондиціювання та зволоження повітря).

Ключові слова: матеріально-технічне забезпечення, органи Казначейства, ресурсне забезпечення, теорія архетипів.

\section{ОПТИМИЗАЦИЯ РЕСУРСНОГО ОБЕСПЕЧЕНИЯ ОРГАНОВ КАЗНАЧЕЙСТВА: АРХЕТИПИЧЕСКИЙ ПОДХОД}

Аннотация. Обозначено, что теория архетипов разработана Карлом Юнгом в рамках учения о коллективном бессознательном. Отмечено, что в современных условиях реформирования общества, органов государственного управления, перехода на новые информационные технологии крайне важно бесперебойное функционирование системы органов Казначейства и управления всеми имеющимися ресурсами: материальными, трудовыми, финансовыми и др. Именно поэтому проблема надлежащего ресурсного обеспечения в органах Казначейства стоит чрезвычайно остро. С целью эффективного выполнения реализации государственной политики в сфере казначейского обслуживания бюджетных средств органы Казначейства на достаточном уровне должны обеспечиваться ресурсами. Осуществлена оценка современного состояния ресурсного обеспечения органов Казначейства в разрезе трех важных составляющих, а именно: приобретение предметов, материалов, оборудования и инвентаря; оплата услуг (кроме коммунальных); приобретение оборудования и предметов долгосрочного использования. Указаны проблемные вопросы материально-технического 
обеспечения органов Казначейства. Освещены достижения в части улучшения материально-технического обеспечения органов Казначейства. Обоснованы принципы дальнейшей оптимизации ресурсного обеспечения органов Казначейства, а именно: предоставление обоснованных предложений Министерству финансов Украины на утверждение бюджетных назначений для осуществления закупки современного компьютерного оборудования, оргтехники, программного обеспечения; осуществления поисков альтернативных финансовых ресурсов для проведения доработки, модернизации и осовременивания существующего программного обеспечения (разработка и утверждение на региональном уровне программ модернизации материального обеспечения органов Казначейства и получения субвенции из местного бюджета в государственный бюджет для проведения расходов); создание надлежащих санитарно-бытовых условий для эффективного выполнения функциональных обязанностей работников (постепенное обустройство рабочих мест вентиляторами, системами кондиционирования и увлажнения воздуха).

Ключевые слова: материально-техническое обеспечение, органы Казначейства, ресурсное обеспечение, теория архетипов.

\section{OPTIMIZATION OF RESOURCE SUPPORT OF THE TREASURY BODIES: ARCHETYPICAL APPROACH}

Abstract. The article notes that the theory of archetypes was developed by Carl Jung as part of the doctrine of the collective unconscious. It is noted that in modern conditions of reforming the society, public administration, transition to the latest information technologies, the smooth functioning of the system of the Treasury bodies and management of all available resources is extremely important: material, labour, financial, etc. That is why the problem of adequate resource support in the Treasury is extremely acute. In order to effectively implement the state policy in the field of treasury servicing of budget funds, the Treasury bodies must be adequately provided with resources. An assessment of the current state of resource support of the Treasury in terms of three important components is made, namely: purchase of items, materials, equipment and inventory; payment for services (except utilities); purchase of equipment and durable goods. Problematic issues concerning the material and technical support of the Treasury bodies are considered. The range of achievements in terms of improving the material and technical support of the Treasury is highlighted.

The principles of further optimization of resource support of the Treasury bodies are substantiated, namely: submission of substantiated proposals to the Ministry of Finance of Ukraine on approval of budget allocations for the purchase of modern computer equipment, office equipment, software; search for alternative financial resources for refinement, modernization of the existing software (development and approval at the regional level of programs for the modernization of the material and technical support of the Treasury and receiving a subvention 
from the local budget to the state budget for expenditures); creation of appropriate sanitary and living conditions for effective performance of functional duties of the employees (gradual arrangement of the workplaces with fans, air conditioning and humidification systems).

Keywords: material and technical support, Treasury bodies, resource support, theory of archetypes.

Постановка проблеми. Ефективність та результативність реалізації державної політики у сфері казначейського обслуговування бюджетних коштів залежить від багатьох чинників, але основним з них є ресурсне забезпечення. В сучасних умовах реформування суспільства, органів державного управління, переходу на новітні інформаційні технології вкрай важливо безперебійне функціонування системи органів Казначейства та управління всіма наявними ресурсами: матеріальними, трудовими, фінансовими тощо. Саме тому проблема належного ресурсного забезпечення в органах Казначейства стоїть надзвичайно гостро.

Аналіз останніх досліджень і публікацій. У науковій літературі проблемам розвитку теорії та практики публічного управління в контексті архетипів національної ментальності в епоху стрімкого розвитку інформаційно-комунікаційних технологій та інновацій присвячено праці сучасних науковців: О. Амосова, Е. Афоніна, Н. Гавкалової, В. Омел'яненка, О. Сушій та ін.

Предметно питання, пов'язані 3 ресурсним забезпеченням як необхідної умови досягнення ефективної, результативної діяльності організації, та якісного рівня надання нею послуг, висвітлено у працях: А. Ю. Ва- сіна, Л. Ю. Гордієнко, А. Ф. Мельник, О. Ю. Оболенського та ін. Проблему раціонального поєднання ресурсних складових в умовах цифровізації економіки і активного впровадження інформаційних технологій опрацьовують науковці Дж. Гелбрейт, Дж. Стігліц, Т. М. Юдіна та ін.

Одначе, відсутність чітких та доступних інформаційних джерел, сервісів, платформ, додатків щодо цифрової трансформації економіки, супротив персоналу щодо нововведень на фоні організаційних змін гальмують швидкість впровадження інновацій у діяльність органів Казначейства, що позначається на якості надання послуг. Визначені проблеми обумовлюють необхідність розроблення нових підходів до оптимізації ресурсного забезпечення діяльності органів Казначейства.

Мета статті. Оцінити сучасний стан ресурсного забезпечення органів Казначейства та обгрунтувати засади його подальшої оптимізації в умовах цифровізації процесів надання послуг в контексті архетипів національної ментальності.

Виклад основного матеріалу дослідження. Теорія архетипів (від др. греч. "Прототип”) - первісна модель, вперше сформований споконвічний тип - була розроблена Карлом Юнгом в рамках вчення про колектив- 
не несвідоме. В образах (архетипах) Юнг бачив джерело загальнолюдської символіки, в тому числі міфів і сновидінь. Універсальні образи або символи, що містяться в колективному несвідомому, привертають індивідуума відчувати певні почуття i мислити певним чином щодо об'єкта або ситуації.

Теорію архетипів можна застосувати на практиці в процесі створення та позиціонування унікального образу особистості або компанії, iї продуктів та послуг. Розуміння архетипів корисно кожної людині, яка займається саморозвитком, прагне розуміти себе та хоче показати свої таланти, а також заявити про себе.

Архетипи несуть в собі успадковані колективні інстинкти, поведінкові програми, які ми реалізовуємо протягом життя. Зовнішні явища, образи, моделі поведінки "запускають" ці програми в частині нашої підсвідомості, де знаходиться колективне несвідоме, змушуючи нас реагувати і добудовувати необхідні елементи, емоції, смисли і сюжети [1].

Роль архетипів особливо зростає в умовах кризових ситуацій у індивідуальному чи спільному житті, а також у моменти вияву творчої активності. За цих обставин відбувається спонтанна активація відповідного архетипу та актуалізується певна послідовність образів, що спливають у свідомості.

На сьогодні теорія Карла Юнга інтенсивно розвивається та набуває нових модифікацій і досить широко використовується на практиці в державному управлінні та управлінні публічними фінансами. Особливо архетипні впливи починають про- являтися зараз, коли, з одного боку, криза охопила всі сфери суспільного життя, а з іншого, інтеграція національної економіки до глобалізованого світу, відкриває нові можливості через доступ до нових технологій, зокрема інформаційних. Що істотно підвищує можливості реалізації творчого потенціалу особистості, а організації - сформувати індивідуальний образ.

Узагальнено в органах Казначейства, як і в інших органах влади, службовці відчувають недостатнє ресурсне забезпечення, що призводить до посилення впливу негативних архетипів. Одним з прикладів є архетип бідності, що характеризує невдоволеність рівнем оплати праці та матеріально-технічним забезпеченням установи, де особа працює, спонукаючи персонал до пошуку іншої сфери прикладання праці. Саме це зумовлює необхідність розгляду шляхів покращення ситуації щодо матеріально-технічного забезпечення органів Казначейства та покращення робочої атмосфери, збереження кадрового потенціалу та мінімізації впливу негативних архетипів.

У сфері управління публічними фінансами провідна роль належить органам Казначейства - суб'єктам реалізації державної політики у сфеpi казначейського обслуговування бюджетних коштів. Задля досягнення кінцевої мети означеної політики, а саме - забезпечення належного, ефективного, економного, цільового та законного використання бюджетних коштів розпорядниками (одержувачами) бюджетних коштів, яких обслуговує Державна казначейська служба України, органи Казначей- 
ства повинні на достатньому рівні бути забезпечені ресурсами, впроваджуючи у практику надання послуг інноваційно-інформаційні технології.

За доцільне вбачаємо здійснення оцінки рівня ресурсного забезпечення органів Казначейства, можливостей впровадження новітніх інформаційних технологій у сферу надання послуг та компетентісної готовності персоналу щодо їх застосування.

Ресурсне забезпечення це сукупність ресурсів, що використовуються чи можуть використовуватися організацією для здійснення своєї діяльності [2]. Воно є головною передумовою успішного функціонування будь-якої установи, організації, підприємства. Зазвичай науковці виокремлюють у складі ресурсного забезпечення наступні ресурси: матеріальні, трудові та фінансові.

Для здійснення ефективної роботи органи Казначейства повинні мати відповідний рівень матеріально-технічного забезпечення, а саме: необхідну кількість обладнання, приладдя, видаткових матеріалів, матеріальних цінностей та мати належні санітарно-побутові умови, а працівники повинні бути забезпечені зручними робочими місцями. В ході реалізації Україною Концепції розвитку цифрової економіки та суспільства України на 2018-2020 рр. [3], впровадження інформаційних технологій в діяльність органів Казначейства потребуватиме гідного забезпечення сучасним комп'ютерним обладнанням, новітніми програмними продуктами, належною системою захисту інформації.

Аналіз матеріально-технічного забезпечення органів Казначейства у Харківській області за 2015-2019 рр. в розрізі трьох важливих складових, a саме: придбання предметів, матеріалів, обладнання та інвентарю; оплата послуг (крім комунальних); придбання обладнання i предметів довгострокового користування наведено на рис.

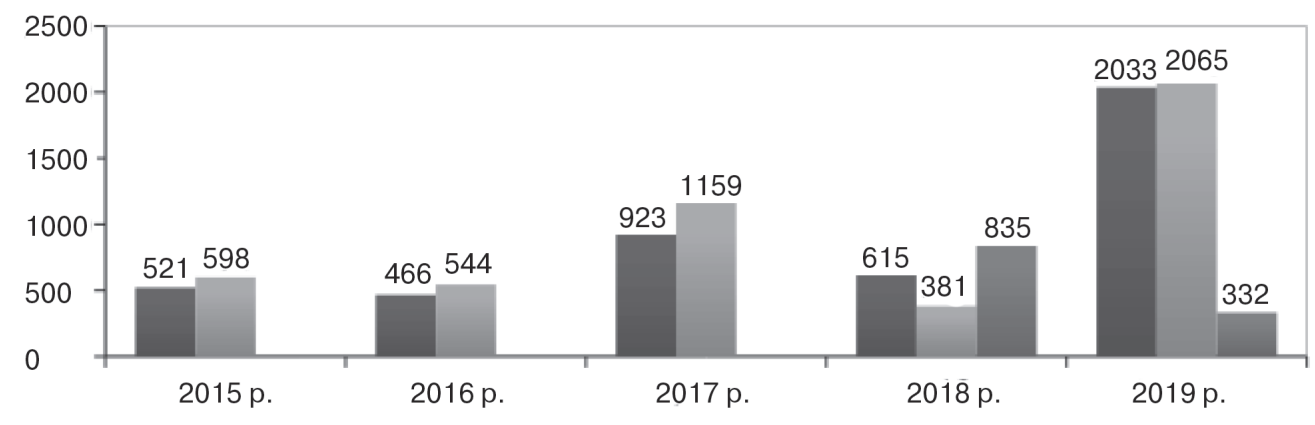

Предмети, матеріали, обладнання та інвентар

Оплата послуг (крім комунальних)

— Придбання обладнання і предметів довгострокового користування

Інформація щодо ресурсного забезпечення органів Казначейства Харківської області у 2015-2019 рр., тис. грн.

Джерело: складено автором за даними [4] 
За першою складовою (придбання предметів, матеріалів, обладнання та інвентарю) спостерігаємо нерівномірне здійснення видатків за роками, але в цілому є дуже стійка позитивна динаміка за останні три роки. Якщо за базу прийняти 2015 р., то у 2017 р. видатки збільшилися на 77 \%, у 2018 р. - на $18 \%$, а у 2019 p. більше майже як у чотири рази. Таке збільшення у 2019 р. відбулося через зростання видатків за наступними напрямами: придбання канцелярського приладдя, конвертів, марок для відправки службової кореспонденції майже в 2 рази, придбання малоцінних предметів (комп'ютерна техніка, оргтехніка) в 81 раз. Разом 3 тим, така позитивна динаміка видатків не супроводжувалася адекватними темпами збільшення витрат на придбання програмного забезпечення в частині текстового редактоpa Microsoft Word та програми для роботи з електронними таблицями Microsoft Excel. В умовах стрімкого розвитку інформаційного суспільства не завжди безкоштовні версії програмних продуктів, наприклад LiberOffice, якими користуються в органах Казначейства, забезпечують належним чином роботу з масивами даних та в певних випадках ускладнюють здійснення робочого процесу. Зауважимо, що збільшення видатків на придбання комплектувальних і дрібних деталей для ремонту обладнання, витратних та інших матеріалів до комп'ютерної техніки та оргтехніки у п'ять разів додатково свідчить про проблеми в частині оновлення оргтехніки, обладнання, а саме що органи Казначейства використовують в роботі багато застарілої техніки. 3 метою запобігання пожеж та захисту працівників у 2019 р. придбано матеріалів для забезпечення виконання вимог пожежної безпеки (вогнегасники, щити, люки) на суму 102610 грн., що в 47 разів більше ніж у 2015 р. (2180 грн.).

За другою складовою - оплата послуг (крім комунальних) видатки проводилися нерівномірно. Так, порівняно з 2015 р. у 2016 та 2018 роках вони зменшувалися відповідно на $10 \%$ (або на 54098 грн.) та $36 \%$ (або на 217447 грн.), натомість у 2017 та 2019 роках збільшувалися відповідно на майже 2 рази (або на 560422 грн.) та 3,5 рази (або на 1466 617 грн.). Найбільша частина видатків припадає на оплату послуг з поточного ремонту та технічного обслуговування обладнання, техніки, механізмів, локальної мережі, систем пожежогасіння, охоронної сигналізації, охорони праці тощо, що склало у 2019 р. 972935 грн., що в 2,5 рази більше ніж у 2015 р. Застаріле обладнання, техніка та несвоєчасне його оновлення супроводжується збільшенням витрат на ремонтні заходи у випадках виходу з ладу обладнання, може призводити до непередбачуваних наслідків в процесі здійснення повноважень та функцій органами Казначейства. Необхідно відмітити, що у 2015 р. видатки з монтажу і установки охоронної та пожежної сигналізації не здійснювалися, що свідчить про недостатній рівень забезпечення охоронною та протипожежною безпекою приміщень органів Казначейства. Але вже у 2019 р. надано фінансування та проведено видатки 3 монтажу і установки охоронної та пожежної сигналізації у 
сумі 453170 грн, а також здійснено видатки на проведення протипожежних заходів (в т. ч. обробка дерев'яних конструкцій вогнетривкою речовиною) у сумі 266859 грн, що на 166 \% більше ніж в 2015 р.

Щодо третьої складової видатків, а саме на придбання обладнання i предметів довгострокового користування, то у 2015-2017 pp. їх не було здійснено. Лише у 2018 р. органи Казначейства отримали 834874 грн, 3 яких на: придбання комп'ютерної техніки (комп'ютери) на суму 489300 грн, офісної техніки (багатофункціональні пристрої) на суму 294699 грн, техніки зв'язку (комутатори) на суму 37500 грн, обладнання для забезпечення функціонування будівель (лічильники обліку теплової енергії, води, газу) на суму 13375 грн. Щоправда, у 2019 р. було отримано коштів на придбання комп'ютерної техніки (комп'ютери) на суму 332196 грн, що в цілому на 157104 грн менше ніж у 2018 р. та склало 67,9 \% від попереднього року.

В умовах зміни кліматичних умов, що зачіпають і територію України, не зайвим буде звернути увагу і на створення належних санітарно-побутових умов на робочих місцях працівників органів Казначейства, а саме: забезпечення системами кондиціювання або кондиціонерами, системами зволоження повітря, вентиляторами. За 25 років існування Казначейства практично не проводилося фінансування цих статей видатків.

Видатки на проведення поточного ремонту будівель, приміщень було профінансовано тільки у 2015 р. на суму 54876 грн та у 2017 р. на суму
158000 грн, що додатково засвідчує недостатній рівень матеріально-технічного забезпечення.

Після проведеного дослідження в розрізі трьох складових матеріально-технічного забезпечення в органах Казначейства у Харківській області можна виділити такі проблемні питання:

- застаріле обладнання, оргтехніка та несвоєчасне фінансування на їх оновлення;

- витрата зайвих фінансових коштів на підтримку працездатності застарілого обладнання та оргтехніки, в умовах обмеженості ресурсів;

- недостатність фінансування для придбання програмного забезпечення, зокрема текстового редактоpa Microsoft Word та програми для роботи $з$ електронними таблицями Microsoft Excel;

- недостатнє фінансування на підтримку в належному стані будівель та приміщень органів Казначейства;

- відсутність фінансування для забезпечення санітарно-побутових умов (забезпеченість системами кондиціювання, кондиціонерами, системами зволоження повітря, вентиляторами).

Але за останні роки є і певні здобутки в частині покращення матеріально-технічного забезпечення, тобто збільшення фінансування та проведення видатків з придбання:

- канцелярського обладнання, конвертів, марок;

- комп'ютерної техніки та оргтехніки;

- матеріалів для забезпечення виконання вимог пожежної безпеки (вогнегасники, щити, люки);

- комплектувальних і дрібних деталей для ремонту обладнання, 
витратних та інших матеріалів до комп'ютерної техніки та оргтехніки;

- монтажу і установки охоронної та пожежної сигналізації.

Для здійснення оптимізації ресурсного забезпечення органів Казначейства необхідно в першу чергу надати до Міністерства фінансів України (далі - МФУ) обгрунтовані пропозиції щодо затвердження бюджетних призначень для здійснення закупівлі сучасного комп'ютерного обладнання, оргтехніки, програмного забезпечення, а також необхідно проводити пошуки альтернативних фінансових ресурсів для здійснення доопрацювання, модернізації та осучаснення існуючого програмного забезпечення. Одним із шляхів вирішення питання щодо отримання достатнього фінансування для придбання сучасного комп'ютерного обладнання, оргтехніки, програмного забезпечення, а також здійснення доопрацювання, модернізації та осучаснення існуючого програмного забезпечення є розробка та затвердження на регіональному рівні програм модернізації матеріального забезпечення органів Казначейства та отримання субвенції з місцевого бюджету до державного бюджету для проведення видатків.

Також при плануванні бюджетних запитів на наступний бюджетний рік необхідно надавати обгрунтовані розрахунки до МФУ щодо належного забезпечення органів Казначейства канцелярським приладдям, конвертами та марками, комплектуючими до комп'ютерної техніки та оргтехніки, виділення коштів для підтримки в належному стані будівель та приміщень органів Казначейства. Крім того, одним із шляхів покращення матеріально-технічного забезпечення органів Казначейства є створення належних санітарно-побутових умов для ефективного виконання функціональних обов'язків працівників, а саме: поступове облаштування робочих місць вентиляторами, системами кондиціювання, зволоження повітря.

Висновки і перспективи подальших досліджень. На підставі викладеного, для того, щоб мінімізувати вплив негативних архетипів при виконанні службових обов'язків працівниками органів Казначейства, перш за все, необхідно зосередити увагу на подальшій оптимізації та покращенні ресурсного забезпечення органів Казначейства. Створення достатнього рівня матеріально-технічного забезпечення для виконання поставлених завдань та повноважень органів Казначейства дозволить здійснити заходи 3: модернізації, доопрацювання та оновлення програмного забезпечення; придбання сучасної комп'ютерної техніки та оргтехніки; створення належних санітарно-побутових умов для ефективного виконання функціональних обов'язків працівників та підвищення рівня задоволення від роботи в цій державній установі.

\section{СПИСОК ВИКОРИСТАНИХ ДЖЕРЕЛ}

1. Архетипы - современный подход: веб-сайт. URL: https://mytype.ru/arhetypes (дата звернення 06.02.2021).

2. Державне управління : навч. посіб./ А. Ф. Мельник, О. Ю. Оболенський, А. Ю. Васіна, Л. Ю. Гордієнко. Київ : Знання-Прес, 2003. 343 с. 
3. Про схвалення Концепції розвитку цифрової економіки та суспільства України на 2018-2020 роки та затвердження плану заходів щодо їі реалізації : розпорядження Кабінету Міністрів України від 17 січня 2018 p. № 67-p. URL: https:// zakon.rada.gov.ua (дата звернення: 06.01.2021).

4. Інформація щодо матеріально-технічного забезпечення органів Казначейства у Харківській області у 2015-2019 pp.

\section{REFERENCES}

1. Arkhetipy - sovremennyi podkhod. [Archetypes - a modern approach]. my-type.ru. Retrieved from https:// my-type.ru/arhetypes [in Ukrainian].

2. Melnyk A. F., Obolenskyi O. Yu., Vasina A. Yu. \& Hordiienko L. Yu. (2003). Derzhavne upravlinnia [Public administration]. Kyiv: Znannia-Pres [in Ukrainian].

3. Rozporiadzhennia Kabinetu Ministriv Ukrainy vid 17 sichnia 2018h. № 67-r "Pro skhvalennia Kontseptsii rozvytku tsyfrovoi ekonomiky ta suspilstva Ukrainy na 2018-2020 roky ta zatverdzhennia planu zakhodiv shchodo ii realizatsii" [Order of the Cabinet of Ministers of Ukraine "On approval of the Concept of development of the digital economy and society of Ukraine for 2018-2020 and approval of the action plan for its implementation" : from 17.01.2018, № 67-r]. (n.d) zakon.rada.gov.ua. Retrieved from https://zakon.rada.gov.ua [in Ukrainian].

4. Informatsiia shchodo materialnotekhnichnoho zabezpechennia orhaniv Kaznacheistva u Kharkivskii oblasti u 2015-2019 rr. 